\title{
Original Article \\ Quercetin inhibited cadmium-induced autophagy in the mouse kidney via inhibition of oxidative stress
}

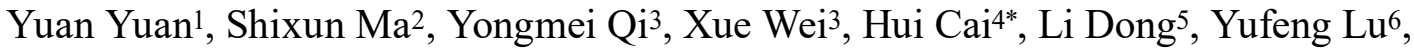 \\ Yupeng Zhang7, and Qingjin Guo ${ }^{7}$
}

\author{
${ }^{1}$ Department of Intensive Medicine, Gansu Provincial Hospital, 204 West Donggang Rd, Lanzhou, Gansu Province, 730000, China \\ 2 Department of General Surgery 1, Gansu Provincial Hospital, 204 West Donggang Rd, Lanzhou, Gansu Province, 730000, China \\ ${ }^{3}$ Gansu Key Laboratory of Biomonitoring and Bioremediation for Environmental Pollution, School of Life Sciences, Lanzhou \\ University, 222 South Tianshui Rd, Lanzhou, Gansu Province, 730000, China \\ ${ }^{4}$ Medical Department, Gansu Provincial Hospital, 204 West Donggang Rd, Lanzhou, Gansu Province, 730000, China \\ ${ }_{5}^{5}$ Department of Centrol Laboratory, Gansu Provincial Hospital, 204 West Donggang Rd, Lanzhou, Gansu Province, 730000, China \\ ${ }^{6}$ Department of Obstetrics, Gansu Provincial Hospital, 204 West Donggang Rd, Lanzhou, Gansu Province, 730000, China \\ ${ }_{7}$ Department of Oncological Surgery, Ningxia Medical University, 1160 South Shengli Rd, Yinchuan, Ningxia Province, 750000, China
}

\begin{abstract}
The objective of the current study was to explore the inhibitory effects of quercetin on cadmium-induced autophagy in mouse kidneys. Mice were intraperitoneally injected with cadmium and quercetin once daily for 3 days. The LC3-II/ $\beta$-actin ratio was used as the autophagy marker, and autophagy was observed by transmission electron microscopy. Oxidative stress was investigated in terms of reactive oxygen species, total antioxidant capacity, and malondialdehyde. Cadmium significantly induced typical autophagosome formation, increased the LC3-II/ $\beta$-actin ratio, reactive oxygen species level, and malondialdehyde content, and decreased total antioxidant capacity. Interestingly, quercetin markedly decreased the cadmium-induced LC3-II/ $\beta$-actin ratio, reactive oxygen species levels, and malondialdehyde content, and simultaneously increased total antioxidant capacity. Cadmium can inhibit total antioxidant capacity, produce a large amount of reactive oxygen species, lead to oxidative stress, and promote lipid peroxidation, eventually inducing autophagy in mouse kidneys. Quercetin could inhibit cadmium-induced autophagy via inhibition of oxidative stress. This study may provide a theoretical basis for the treatment of cadmium injury. (DOI: 10.1293/tox.2016-0026; J Toxicol Pathol 2016; 29: 247-252)
\end{abstract}

Key words: quercetin, cadmium, autophagy, inhibition, mouse kidney

\section{Introduction}

Cadmium (Cd) is one of the most common toxic heavy metals. It can harm human beings in various ways, and hence, prevention and treatment for $\mathrm{Cd}$ poisoning is of great significance ${ }^{2,3}$.

Autophagy is a conserved metabolic pathway in which cellular components can be degraded and reused by eukaryotic cells ${ }^{4}$. Microtubule-associated protein light chain 3 (LC3) is considered to be a characteristic protein of autophagy3. When autophagy is initiated, LC3 is enzymolysized into the cytosolic type (LC3-I), which then combines with phosphatidylethanolamine (PE) to transform into the membrane type (LC3-II) $)^{5}$. The level of autophagy can be

Received: 15 April 2016, Accepted: 4 July 2016

Published online in J-STAGE: 18 August 2016

*Corresponding author: H Cai (e-mail: caialon@163.com)

(C)2016 The Japanese Society of Toxicologic Pathology

This is an open-access article distributed under the terms of the Creative Commons Attribution Non-Commercial No Derivatives (by-ncnd) License $<$ http://creativecommons.org/licenses/by-nc-nd/4.0/> . estimated by detecting the LC3-II/ $\beta$-actin ratio using western blotting 6 . Transmission electron microscopy is one of the best approaches to provide direct evidence for autopha$\mathrm{gy}^{2,7}$. On the other hand, autophagy is also morphologically defined, especially by transmission electron microscopy, as massive autophagic vacuolization of the cytoplasm (autophagosome) $^{8}$.

Recent studies showed that $\mathrm{Cd}$ can affect the body's (or cell's) antioxidant system ${ }^{4}$, change the activity of antioxidant enzymes, and make the body (or cell) to produce a large amount of ROS, thus leading to oxidative stress ${ }^{3,9-11}$. In addition, Cd can induce ROS-mediated autophagy of kidney cells via a series of pathways ${ }^{2}$ and can induce mitophagy through the ROS-mediated PTEN-induced putative kinase 1/ Parkin (PINK1/Parkin) pathway in the kidneys of micel, 2 .

Quercetin $\left(3,3^{\prime}, 4,5,7\right.$-pentahydroxyavone) $(\mathrm{Qu})$ and its derivatives are the most widely distributed plant kingdom flavonoids, which act as antioxidants by scavenging free radicals ${ }^{12,13}$. Qu exerts its antioxidant effect by scavenging free radicals directly ${ }^{12-15}$, and it is a renoprotective drug in Traditional Chinese Medicine (TCM). However, it is unknown whether Qu can inhibit Cd-induced autophagy in the 
mouse kidney, and the underlying molecular mechanisms for such an effect have not been explored and reported.

Our study investigated how Qu inhibits Cd-induced autophagy in mouse kidneys.

\section{Materials and Methods}

\section{Chemicals}

Qu (99\% purity) was purchased from Aladdin Chemical Reagent Plant (Shanghai, China). CdCl2 (99\% purity) and dimethyl sulfoxide (DMSO) (99\% purity) were obtained from Tianjin Chemical Reagent Plant (Tianjin, China). Sodium chloride injection $(0.9 \%$, NS) was purchased from Guangdong Otsuka Plant (Guangdong, China). A total antioxidant ability detection kit (FRAP method), BCA protein assay kit, and lipid peroxidation (MDA) detection kits were obtained from Beyotime Biotechnology Co. Ltd. (Jiangsu, China).

\section{Animals}

One-month-old male Kunming mice, weighing 22.0 $\pm 2.0 \mathrm{~g}$ were obtained from the Experimental Animal Research Center of Lanzhou University (Lanzhou, China). The mice were acclimated in the laboratory for one week before the experiments, maintained at a room temperature of $22-24^{\circ} \mathrm{C}$ with alternating 12 hour light/dark cycles, offered water and food ad libitum, and provided with adequate levels of lighting and humidity.

In the preliminary experiments, the mice were intraperitoneally injected with different concentrations of $\mathrm{Cd}$ $(0.20,0.40,0.60$, and $0.80 \mathrm{mg} / \mathrm{kg}$ bw/day) once daily for 1,2 , 3 , and 5 days, and the LC3-II/ $\beta$-actin ratio was determined. We found that autophagy was most obviously induced after $0.40 \mathrm{mg} / \mathrm{kg}$ bw/day $\mathrm{Cd}$ exposure for 3 days, and hence, 0.40 $\mathrm{mg} / \mathrm{kg}$ bw/day $\mathrm{Cd}$ was selected for the following experiments.

Qu was initially dissolved in DMSO to make a $200 \mathrm{mg} /$ $\mathrm{kg}$ stock solution (pure), diluted to twice the required concentration with pure DMSO, blended with the same volume of NS or $0.8 \mathrm{mg} / \mathrm{kg} \mathrm{Cd}$ before use, and finally used after cooling to room temperature.

Mice were randomly divided into a control group, $\mathrm{Cd}$ treated group, and co-treated groups (treated with $0,5,15$, 25, 50, 75, and $100 \mathrm{mg} / \mathrm{kg}$ bw/day Qu and $0.4 \mathrm{mg} / \mathrm{kg}$ bw/ day $\mathrm{Cd}$ ), each of which contained 8 mice. The mice were intraperitoneally injected with $\mathrm{NS}, 0.40 \mathrm{mg} / \mathrm{kg}$ bw/day $\mathrm{Cd}$, and different concentrations of mixed solutions of $\mathrm{Qu}$ and $\mathrm{Cd}$ in the same proportion ( $5 \mu \mathrm{l} / \mathrm{g}$ bw/day) once daily for 3 days. The detailed scheme of mouse treatments is described in Table 1.

The physical condition of the animals was monitored for 25 minutes three times per day. All mice showed good activity levels and feeding, with no obvious change in body weight, and did not exhibit any special symptoms.

On the 4th day, all mice were intraperitoneally injected with xylazine $(100 \mathrm{mg} / \mathrm{kg} \mathrm{bw})$. After anesthesia, the chest and abdomen were opened, and the heart was perfused with
Table1. The Detailed Scheme of Mouse Treatments

\begin{tabular}{|c|c|}
\hline Groups & Treatments \\
\hline Control group & $0.9 \%$ sodium chloride injection $(\mathrm{NS})$ \\
\hline Cd-treated group & $0.40 \mathrm{mg} / \mathrm{kg}$ bw/day $\mathrm{Cd}$ \\
\hline \multirow[t]{7}{*}{ Co-treated groups } & $0 \mathrm{mg} / \mathrm{kg}$ bw/day Qu and $0.4 \mathrm{mg} / \mathrm{kg}$ bw/day $\mathrm{Cd}$ \\
\hline & $5 \mathrm{mg} / \mathrm{kg}$ bw/day $\mathrm{Qu}$ and $0.4 \mathrm{mg} / \mathrm{kg}$ bw/day $\mathrm{Cd}$ \\
\hline & $15 \mathrm{mg} / \mathrm{kg}$ bw/day $\mathrm{Qu}$ and $0.4 \mathrm{mg} / \mathrm{kg}$ bw/day $\mathrm{Cd}$ \\
\hline & $25 \mathrm{mg} / \mathrm{kg}$ bw/day $\mathrm{Qu}$ and $0.4 \mathrm{mg} / \mathrm{kg}$ bw/day $\mathrm{Cd}$ \\
\hline & $50 \mathrm{mg} / \mathrm{kg}$ bw/day Qu and $0.4 \mathrm{mg} / \mathrm{kg}$ bw/day $\mathrm{Cd}$ \\
\hline & $75 \mathrm{mg} / \mathrm{kg}$ bw/day Qu and $0.4 \mathrm{mg} / \mathrm{kg}$ bw/day $\mathrm{Cd}$ \\
\hline & $100 \mathrm{mg} / \mathrm{kg}$ bw/day $\mathrm{Qu}$ and $0.4 \mathrm{mg} / \mathrm{kg}$ bw/day $\mathrm{Cd}$ \\
\hline
\end{tabular}

$10 \mathrm{~mL}$ of PBS buffer (cold at $4^{\circ} \mathrm{C}, \mathrm{pH}$ 7.4). The kidney was removed and fascia was peeled ${ }^{13}$. All experiments were performed in accordance the Guidelines for Care and Use of Animals at Lanzhou University.

\section{Transmission electron microscopy}

Tissues from the kidney cortex of the control and Cdtreated group of mice were cut into $0.3 \times 0.3 \times 0.3 \mathrm{~cm}^{3}$ blocks and fixed with $1 \mathrm{ml}$ of $2.5 \%$ glutaraldehyde. The fixative was replaced with fresh liquid every $24 \mathrm{~h}$ until the samples were sent to the electron microscope facility of Lanzhou University. The samples were then postfixed in OsO4, dehydrated in ethanol and acetone, and embedded in resin. Ultrathin sections $(60-70 \mathrm{~nm})$ were cut and mounted on pioloformcoated copper grids (Plano). Sections were stained with lead citrate and uranyl acetate and viewed with a transmission electron microscope (JEOL JEM-1230, JEOL Ltd., Japan) operated at $80 \mathrm{kV}$. Micrographs were taken using a Gatan Erlangshen ES500W camera.

\section{Measurement of ROS}

The renal cortex tissues were collected in $1.5 \mathrm{~mL}$ centrifuge tubes, and finely cut. PBS (cold at $4^{\circ} \mathrm{C}, \mathrm{pH}$ 7.4) was added to the samples, filtered with 200-mesh stainless steel mesh, centrifuged at $500 \mathrm{rpm}$ for $8 \mathrm{~min}$, and then washed twice with PBS. The cells were counted and adjusted to $1 \times$ $10^{6}$ cells/mL in each tube, and $1 \mathrm{~mL}$ of $10 \mu \mathrm{M}$ 2,7-dichlorodihydrofluorescein diacetate (DCFH-DA) was added. Then the contents within each tube were mixed, and the tubes were incubated at $37^{\circ} \mathrm{C}$ for $30 \mathrm{~min}$. The samples were then centrifuged at $1,000 \mathrm{rpm}$ for $5 \mathrm{~min}$, washed three times, and filtered with a 200 -mesh nylon membrane into a flow tube. ROS were analyzed using flow cytometry (FCM) (BD Biosciences, Franklin Lakes, NJ, USA) at the excitation and emission settings for FITC (excitation $488 \mathrm{~nm}$, emission 525 $\mathrm{nm}$ ). At least 5,000 cells were detected, and all of the above operations were carried out on ice. The incubation process required dark conditions and was completed within $4 \mathrm{~h}$.

\section{Preparation of tissue homogenates}

A suitable amount of the kidney cortex tissues (about $200 \mathrm{mg}$ from each group) was transferred into $1.5 \mathrm{~mL}$ centrifuge tubes to make tissue homogenates. The samples were frozen by immersion in liquid nitrogen for $30 \mathrm{~s}$ and 
then mashed. This was followed by the addition of $1 \mathrm{~mL}$ $1 \times$ PBS buffer and $10 \mu \mathrm{L} 0.1 \mathrm{mM}$ PMSF solution, mixing of the contents within each tube, and pulverization with a SCIENTZ-IID ultrasonic cell crushing apparatus (total time, 10 min; open, $5 \mathrm{~s}$; close, $5 \mathrm{~s}$; power, $25 \%$ ). The samples were centrifuged at $12,000 \mathrm{~g}$ for $10 \mathrm{~min}$ at $4^{\circ} \mathrm{C}$, and the supernatant was collected; the precipitate was discarded. The tissue homogenates were diluted 20 -fold, and the protein concentration was detected with a bicinchonininc acid (BCA) protein assay kit. The prepared tissue homogenates were used to detect the total protein concentration, total antioxidant capacity (T-AOC), and MDA and for western blotting (all of the operations were carried out on ice).

\section{Western blotting}

Electrophoresis protein samples and tissue homogenates were prepared at appropriate sample volumes based on the protein concentration. Protein samples were separated by SDS-PAGE $(15 \%$ gel; $60 \mathrm{~V}$ for $30 \mathrm{~min}$ and then $120 \mathrm{~V}$ for $90 \mathrm{~min}$ ). The protein was transferred onto 0.22 $\mu \mathrm{m}$ polyvinylidene fluoride (PVDF) membranes (electric current $200 \mathrm{~mA}, 90 \mathrm{~min}$ ), which were blocked with $5 \%$ skimmed milk powder solution $\left(27^{\circ} \mathrm{C}, 60 \mathrm{~min}\right)$. The PVDF membranes were cut into two parts; one part was used for incubation $\left(4^{\circ} \mathrm{C}\right.$, overnight) with anti-LC3 (1:2,000, mouse monoclonal, Sigma-Aldrich, St. Louis, MO, USA), and the other one was use for incubation $\left(4^{\circ} \mathrm{C}\right.$, overnight $)$ with anti$\beta$-actin (1:2,000, rabbit polyclonal, Sigma-Aldrich). The membranes were washed three times with Tris Buffered Saline with Tween-20 (TBST) buffer and then incubated with horseradish peroxidase (HRP)-conjugated secondary antibodies $\left(27^{\circ} \mathrm{C}, 60 \mathrm{~min}\right)$, anti-mouse (1:20,000, goat polyclonal, ZhongShan Golden Bridge Biotechnology, Beijing, China) or anti-rabbit (1:20,000, goat polyclonal, ZhongShan Golden Bridge Biotechnology), and LC3 and $\beta$-actin were detected with the Immobilon Western Chemiluminescent HRP Substrate (Millipore, Billerica, MA, USA).

\section{Detection kits}

Detection of total protein concentration, MDA, and TAOC was carried out according to the manufacturer's instructions. The standard curves were prepared, and then the concentrations of the substances in the test samples were measured and presented as the content of the samples.

\section{Statistical analysis}

The results were processed with the Excel 2003, Origin 75, FlowJo 7.6, ImageJ, and iSee software. Data were expressed as mean $\pm \mathrm{SD}$ values $(\mathrm{n}=8)$. Statistical comparisons were made using one-way analysis of variance (ANOVA) followed by the least significant difference (LSD) post hoc test. All statistical analyses were performed using the SPSS 17.0. Differences were considered significant at $\mathrm{P}<0.05$ and highly significant at $\mathrm{P}<0.01^{1}$.

\section{Results}

\section{Cd induced autophagy in the mouse kidney}

To quantify autophagy progression, we detected conversion of the cellular protein LC3-I to LC3-II (autophagy marker). In preliminary experiments, mice were intraperitoneally injected with different concentrations of $\mathrm{Cd}(0.20$, $0.40,0.60$, and $0.80 \mathrm{mg} / \mathrm{kg} \mathrm{bw} /$ day) once daily for $1,2,3$, and 5 days. Compared with control exposure, exposure to $0.20,0.40,0.60$, and $0.80 \mathrm{mg} / \mathrm{kg}$ bw/day Cd for 3 days markedly elevated the LC3-II/ $\beta$-actin ratio $1.35-, 1.47-, 1.31-$, and 1.27 -fold in the kidneys of mice $(\mathrm{P}<0.05$ except for $0.40 \mathrm{mg} /$ $\mathrm{kg}$ bw/day $\mathrm{Cd}$, in which case $\mathrm{P}<0.01$ ), respectively (Fig. 1A). Therefore, $0.40 \mathrm{mg} / \mathrm{kg}$ bw/day $\mathrm{Cd}$ was selected for the following experiments.

Compared with control exposure, exposure to $0.4 \mathrm{mg} /$ $\mathrm{kg}$ bw/day Cd induced typical double-membrane and lamellar autophagosomes in the epithelia of proximal tubules after 3 days of treatment (Fig. 1B). Multiple typical autophagosomes were found in the perinuclear area, and the mitochondria were contained in autophagic vacuoles.

\section{Qu inhibited Cd-induced autophagy in the mouse kidney}

Mice were injected with NS or Cd $(0.40 \mathrm{mg} / \mathrm{kg}$ bw/day $)$ alone or in combination with Qu $(0,5,15,25,50,75$, and 100 $\mathrm{mg} / \mathrm{kg}$ bw/day) for 3 days, and then the LC3-I, LC3-II, and $\beta$-actin levels were determined by western blotting. Compared with control exposure, $0.40 \mathrm{mg} / \mathrm{kg}$ bw/day $\mathrm{Cd}$ exposure for 3 days markedly elevated the LC3-II/ $\beta$-actin ratio in the kidneys of mice $(\mathrm{P}<0.01)$. There was no significant difference in the LC3-II/ $\beta$-actin ratio in the kidneys $(\mathrm{P}>0.05)$ between the Cd-treated group and the mice co-treated with $\mathrm{Qu}(0 \mathrm{mg} / \mathrm{kg}$ bw/day). Among the Qu co-treated groups, the groups treated with $5,15,25,50,75$, and $100 \mathrm{mg} / \mathrm{kg}$ bw/ day Qu for 3 days showed markedly reduced LC3-II/ $\beta$-actin ratios (1.15-, 1.24-, 1.47-, 1.43-, 1.41-, and 1.26-fold), in the kidneys $(\mathrm{P}<0.01$ except for $5 \mathrm{mg} / \mathrm{kg}$ bw/day Qu exposure, in which case $\mathrm{P}<0.05$ ) respectively (Fig. 2 ).

\section{Qu inhibited Cd-induced autophagy in mouse kidney cells via inhibition of oxidative stress}

The mice were injected with NS or Cd $(0.40 \mathrm{mg} / \mathrm{kg}$ bw day), alone or in combination with $\mathrm{Qu}(0,5,15,25,50,75$, and $100 \mathrm{mg} / \mathrm{kg} \mathrm{bw} /$ day), for 3 days, and then the T-AOC and MDA were determined with detection kits. The levels of ROS in the mouse kidney were determined by FCM.

Compared with control exposure, $0.40 \mathrm{mg} / \mathrm{kg}$ bw/day $\mathrm{Cd}$ exposure for 3 days markedly reduced the $\mathrm{T}-\mathrm{AOC}$ in the kidneys of mice $(\mathrm{P}<0.01)$. Compared with the $\mathrm{Cd}$-treated group, the mice in the $\mathrm{Qu}(0 \mathrm{mg} / \mathrm{kg}$ bw/day $)$ co-treated group showed no significant difference $(\mathrm{P}>0.05)$ in the T-AOC in the kidneys. Among the $\mathrm{Qu}$ co-treated groups, the groups treated with $5,15,25,50,75$, and $100 \mathrm{mg} / \mathrm{kg}$ bw/day Qu for 3 days showed an obvious improvement in the T-AOC in the kidneys of mice $(\mathrm{P}<0.01$ except for $5 \mathrm{mg} / \mathrm{kg}$ bw/day $\mathrm{Qu}$ exposure, in which case $\mathrm{P}<0.05$ ) (Fig. $3 \mathrm{~A}$ ). 

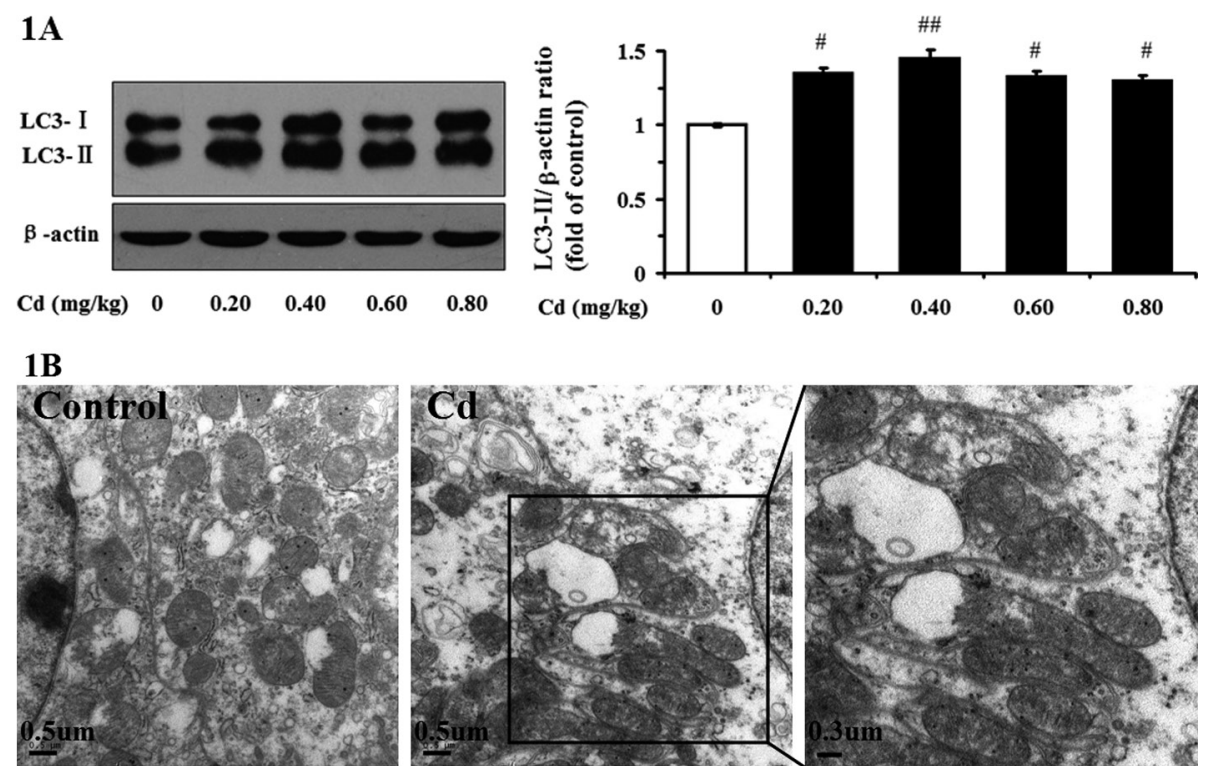

Fig. 1. Cd induced autophagy in the mouse kidney. The mice were received either NS (control, $0 \mathrm{mg} / \mathrm{kg}$ bw/day) or a daily intraperitoneal injection of $\mathrm{Cd}(0.20,0.40,0.60$, and $0.80 \mathrm{mg} / \mathrm{kg}$ bw/day) once daily for 3 days. (1A) LC3-I, LC3-II, and $\beta$-actin levels were detected by western blotting. (1B) (Cd $0.40 \mathrm{mg} / \mathrm{kg}$ bw/day) Transmission electron microscopy showed double-membrane and lamellar mitophagosomes in the epithelia of proximal tubules. Data are presented as mean $\pm \mathrm{SD}$ values $(\mathrm{n}=8)$. \#, \#\#ignificantly different from the control group at $\mathrm{P}<0.05$ and $\mathrm{P}<0.01$, respectively.
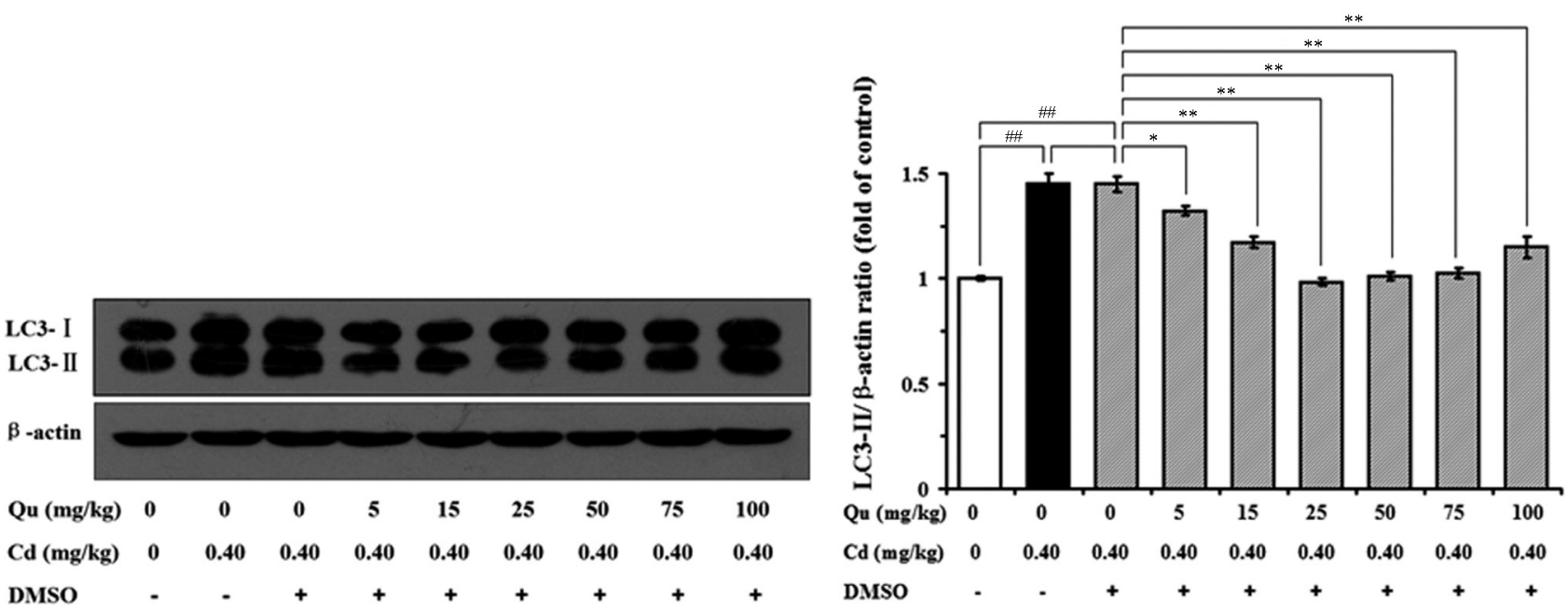

Fig. 2. Qu inhibited Cd-induced autophagy in the mouse kidney. The mice were injected with NS or Cd ( $0.40 \mathrm{mg} / \mathrm{kg}$ bw/day) alone or in combination with Qu $(0,5,15,25,50,75$, and $100 \mathrm{mg} / \mathrm{kg}$ bw/day) once daily for 3 days, and then the LC3-I and LC3-II levels were detected by western blotting. Data are presented as mean \pm SD values $(n=8)$. \#, \#\#ignificantly different from the control group at $\mathrm{P}<0.05$ and $\mathrm{P}<0.01$, respectively. ${ }^{*}{ }^{*}$ Significantly different from the $\mathrm{Qu}(0 \mathrm{mg} / \mathrm{kg}$ bw/day $)$ co-treated group at $\mathrm{P}<0.05$ and $\mathrm{P}<0.01$, respectively.

Compared with control exposure, $0.40 \mathrm{mg} / \mathrm{kg} \mathrm{bw} /$ day $\mathrm{Cd}$ exposure for 3 days markedly elevated the MDA levels in the kidneys of mice $(\mathrm{P}<0.01)$. Compared with the Cd-treated group, the mice in the $\mathrm{Qu}(0 \mathrm{mg} / \mathrm{kg}$ bw/day $)$ cotreated group showed no significant difference $(\mathrm{P}>0.05)$ in the MDA levels in the kidneys. Among the Qu co-treated groups, the groups treated with $5,15,25,50,75$, and 100 $\mathrm{mg} / \mathrm{kg}$ bw/day Qu for 3 days showed markedly reduced the MDA levels in the kidneys $(\mathrm{P}<0.01)$ (Fig. 3B).
It was also found that, $0.40 \mathrm{mg} / \mathrm{kg}$ bw/day Cd exposure for 3 days markedly elevated the levels of ROS in the kidneys of mice $(\mathrm{P}<0.01)$. There was no significant difference in ROS levels in the kidneys of mice between the $\mathrm{Cd}$ treated group and $\mathrm{Qu}(0 \mathrm{mg} / \mathrm{kg}$ bw/day) co-treated groups $(\mathrm{P}>0.05)$. Among the $\mathrm{Qu}$ co-treated groups, the groups treated with $5,15,25,50,75$, and $100 \mathrm{mg} / \mathrm{kg}$ bw/day Qu for 3 days showed markedly reduced ROS levels in the kidneys $(\mathrm{P}<0.01)$ (Fig. 3C). 

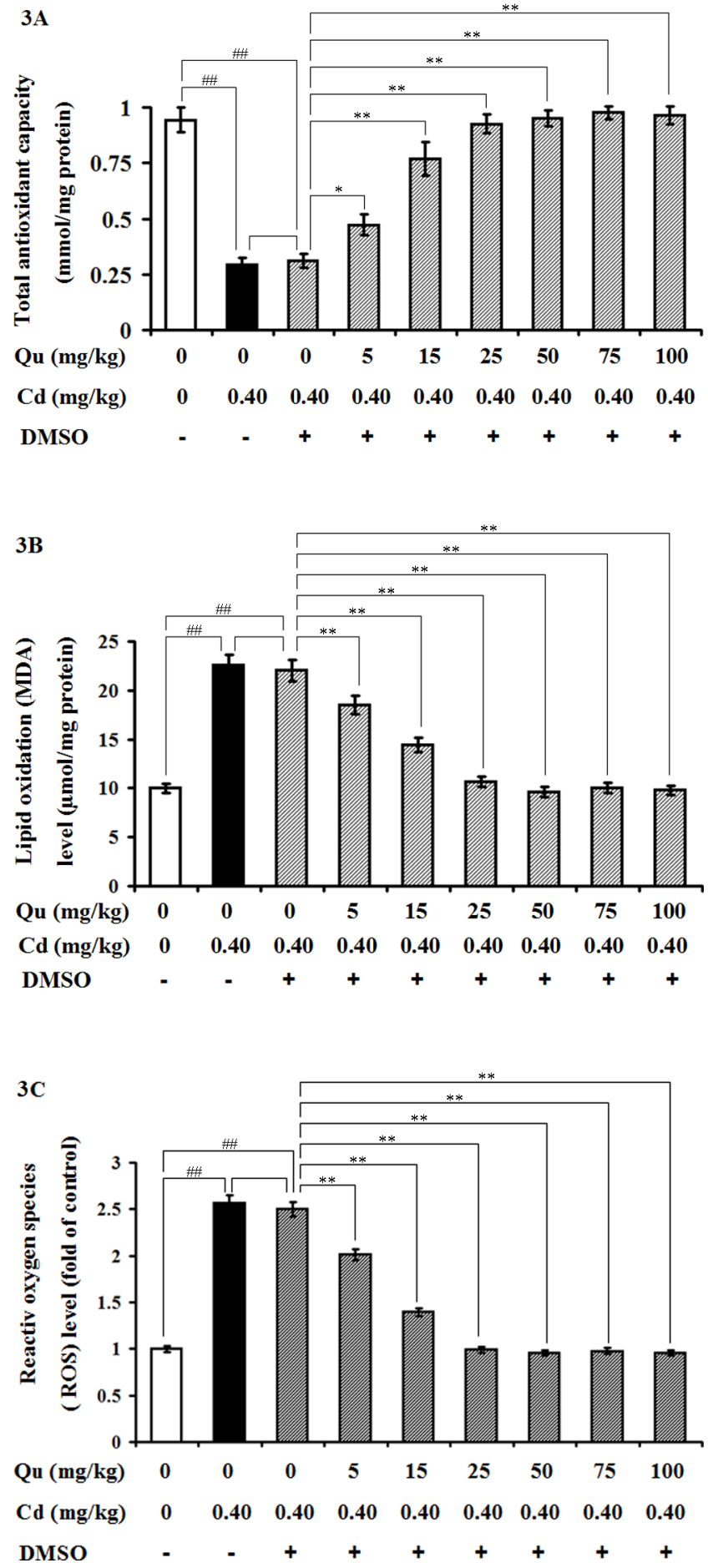

Fig. 3. Qu inhibited Cd-induced autophagy in mouse kidney cells via inhibition of oxidative stress. The mice were injected with $\mathrm{Cd}(0.40 \mathrm{mg} / \mathrm{kg}$ bw/day $)$ alone or in combination with $\mathrm{Qu}(0$, $5,15,25,50,75$, and $100 \mathrm{mg} / \mathrm{kg}$ bw/day) once daily for 3 days, and then the total antioxidant capacity (3A) and lipid oxidation levels (MDA) (3B) were detected with detection kits. The levels of ROS (3C) in the mouse kidney were detected by flow cytometry $(\mathrm{FCM})$. Data are presented as mean $\pm \mathrm{SD}$ values $(\mathrm{n}=8)$. \#, \#Significantly different from the control group at $\mathrm{P}<0.05$ and $\mathrm{P}<0.01$, respectively. $* * *$ Significantly different from the $\mathrm{Qu}(0 \mathrm{mg} / \mathrm{kg}$ bw/day $)$ co-treated group at $\mathrm{P}<0.05$ and $\mathrm{P}<0.01$, respectively.

\section{Discussion}

Acute or chronic exposure to Cd can damage many organs, with the kidney being the most sensitive and vulnerable one ${ }^{16,17}$. Previous studies have shown that $\mathrm{Cd}$ can cause damage to renal tubular epithelial cells ${ }^{18}$. Specifically, Cd could trigger cellular damages such as necrosis, apoptosis, and autophagy ${ }^{19}$. Relatively high concentrations of $\mathrm{Cd}$ can induce apoptosis and necrosis in general, while low concentration can cause autophagy ${ }^{2,12}$.

Autophagy is an adaptive mechanism that responds to changing environmental stimuli, such as starvation and oxidative stress. Therefore, signal transduction can promote cell survival ${ }^{20}$. Under cellular homeostasis conditions, autophagy plays a housekeeping role in the circulation of cytoplasmic components and protein ${ }^{21}$. Under stress conditions, cells remove harmful particles and protein aggregates through autophagy to prevent cell death ${ }^{22}$. However, autophagic cell death can occur when a large number of cells are destroyed and cleared ${ }^{12}$. Autophagy is related to numerous physiological and pathological processes, including cell survival, cell death, cell metabolism, development, infection, immunity, and aging ${ }^{11,23,24}$. It has also been found to be closely involved in the etiology of many important human diseases, including cancer, neurodegenerative diseases, and metabolic disorders 5,22 .

In this study, mice were intraperitoneally injected with $\mathrm{Cd}(5 \mu \mathrm{l} / \mathrm{g}$ bw/day) for 3 days to establish a Cd-induced mouse kidney autophagy model successfully (Fig. 1 and Fig. 2). Moreover, $0.40 \mathrm{mg} / \mathrm{kg} \mathrm{Cd}$ induced autophagy most obviously $(\mathrm{P}<0.01)$. DMSO was used to dissolve quercetin, and 7 concentrations of quercetin $(0,5,15,25,50.75$ and $100 \mathrm{mg} / \mathrm{kg}$ ) were chosen for the experiments. DMSO was selected to dissolve Qu because there was no difference in LC3-II/ $\beta$-actin ratio between the $C d$-treated group and a $\mathrm{Qu}$ $(0 \mathrm{mg} / \mathrm{kg}$ bw/day) co-treated group (50\% DMSO did not affect the LC3-II/ $\beta$-actin ratio). When the concentration of $\mathrm{Qu}$ was more than $100 \mathrm{mg} / \mathrm{kg}$, Qu could not dissolve in $50 \%$ DMSO. In the co-treatment group, each concentration of $\mathrm{Qu}$ was combined with $0.4 \mathrm{mg} / \mathrm{kg} \mathrm{Cd}$ and intraperitoneally injected into the mice for 3 days. We found that 5 to 100 $\mathrm{mg} / \mathrm{kg} \mathrm{Qu}$ inhibited Cd-induced autophagy in mouse kidney cells $(\mathrm{P}<0.05)$ and that the inhibitory effect of quercetin at the dose of $25 \mathrm{mg} / \mathrm{kg}$ was highly significant $(\mathrm{P}<0.01$, Fig. 2).

The results showed that $\mathrm{Cd}$ significantly induced typical autophagosome formation (Fig 1B), increased the LC3II/ $\beta$-actin ratio (Fig. 1A and Fig. 2), enhanced ROS levels (Fig. 3C) and MDA content (Fig. 3B), and decreased the T-AOC (Fig. 3A). Qu markedly decreased the Cd-induced LC3-II/ $/$-actin ratio (Fig. 2), ROS levels (Fig. 3C), and MDA content (Fig. 3B), but it simultaneously increased the T-AOC (Fig. 3A).

The results indicated that $\mathrm{Cd}$ inhibited the T-AOC of mouse kidneys, induced production of a large amount of ROS, leading to oxidative stress, and promoted intracellular lipid oxidation, eventually leading to autophagy in mouse kidney cells. Qu might reduce the generation of ROS in cells to inhibit oxidative stress and inhibit intracellular lipid oxi- 
dation, ultimately inhibiting the autophagy of mouse kidney cells induced by cadmium via an increase in the T-AOC of the mouse kidney.

Taken together, the findings suggest that Qu may play a protective role in Cd-induced mouse kidney injury through its antioxidant activity. This study provides a theoretical basis for treatment of Cd injury. Qu may have some protective effects on the kidney by decreasing Cd-induced injury and may have certain social and economic benefits.

Acknowledgments: This study was supported by the Traditional Chinese Medicine Science and Technology Plan Projects in Gansu Province (Fund No. GZK-2012-61) and the Environmental Protection Science and Technology Plan Projects in Gansu Province (Fund No. GSEP - 2014-24).

Disclosure of Potential Conflicts of Interest: The authors declare that there are no conflicts of interest.

\section{References}

1. Wei X, Qi Y, Zhang X, Qiu Q, Gu X, Tao C, Huang D, and Zhang Y. Cadmium induces mitophagy through ROSmediated PINK1/Parkin pathway. Toxicol Mech Methods. 24: 504-511. 2014. [Medline] [CrossRef]

2. Chargui A, Zekri S, Jacquillet G, Rubera I, Ilie M, Belaid A, Duranton C, Tauc M, Hofman P, Poujeol P, El May MV, and Mograbi B. Cadmium-induced autophagy in rat kidney: an early biomarker of subtoxic exposure. Toxicol Sci. 121: 31-42. 2011. [Medline] [CrossRef]

3. Wei X, Qi Y, Zhang X, Gu X, Cai H, Yang J, and Zhang Y. ROS act as an upstream signal to mediate cadmiuminduced mitophagy in mouse brain. Neurotoxicology. 46: 19-24. 2015. [Medline] [CrossRef]

4. Chiarelli R, and Roccheri MC. Heavy metals and metalloids as autophagy inducing agents: focus on cadmium and arsenic. Cells. 1: 597-616. 2012. [Medline] [CrossRef]

5. Debnath J, Baehrecke EH, and Kroemer G. Does autophagy contribute to cell death? Autophagy. 1: 66-74. 2005. [Medline] [CrossRef]

6. Huber TB, Edelstein CL, Hartleben B, Inoki K, Jiang M, Koya D, Kume S, Lieberthal W, Pallet N, Quiroga A, Ravichandran K, Susztak K, Yoshida S, and Dong Z. Emerging role of autophagy in kidney function, diseases and aging. Autophagy. 8: 1009-1031. 2012. [Medline] [CrossRef]

7. Toyokuni S. Molecular mechanisms of oxidative stress-induced carcinogenesis: from epidemiology to oxygenomics. IUBMB Life. 60: 441-447. 2008. [Medline] [CrossRef]

8. Son YO, Wang X, Hitron JA, Zhang Z, Cheng S, Budhraja A, Ding S, Lee JC, and Shi X. Cadmium induces autophagy through ROS-dependent activation of the LKB1-AMPK signaling in skin epidermal cells. Toxicol Appl Pharmacol. 255: 287-296. 2011. [Medline] [CrossRef]

9. Cuypers A, Plusquin M, Remans T, Jozefczak M, Keunen E, Gielen H, Opdenakker K, Nair AR, Munters E, Artois TJ, Nawrot T, Vangronsveld J, and Smeets K. Cadmium stress: an oxidative challenge. Biometals. 23: 927-940. 2010. [Medline] [CrossRef]

10. Gibellini L, Pinti M, Nasi M, Montagna JP, De Biasi S, Roat E, Bertoncelli L, Cooper EL, and Cossarizza A. Quercetin and cancer chemoprevention. Evid Based Complement Al- ternat Med. 2011: 591356. 2011. [Medline] [CrossRef]

11. Boots AW, Drent M, de Boer VC, Bast A, and Haenen GR. Quercetin reduces markers of oxidative stress and inflammation in sarcoidosis. Clin Nutr. 30: 506-512. 2011. [Medline] [CrossRef]

12. Ishisaka A, Ichikawa S, Sakakibara H, Piskula MK, Nakamura T, Kato Y, Ito M, Miyamoto K, Tsuji A, Kawai Y, and Terao J. Accumulation of orally administered quercetin in brain tissue and its antioxidative effects in rats. Free Radic Biol Med. 51: 1329-1336. 2011. [Medline] [CrossRef]

13. Wang K, Liu R, Li J, Mao J, Lei Y, Wu J, Zeng J, Zhang $\mathrm{T}$, Wu H, Chen L, Huang C, and Wei Y. Quercetin induces protective autophagy in gastric cancer cells: involvement of Akt-mTOR- and hypoxia-induced factor $1 \alpha$-mediated signaling. Autophagy. 7: 966-978. 2011. [Medline] [CrossRef]

14. Zhong J, Guo D, Chen CB, Wang W, Schuster M, Loibner H, Penninger JM, Scholey JW, Kassiri Z, and Oudit GY. Prevention of angiotensin II-mediated renal oxidative stress, inflammation, and fibrosis by angiotensin-converting enzyme 2. Hypertension. 57: 314-322. 2011. [Medline] [CrossRef]

15. Jing Y, Liu LZ, Jiang Y, Zhu Y, Guo NL, Barnett J, Rojanasakul Y, Agani F, and Jiang BH. Cadmium increases HIF-1 and VEGF expression through ROS, ERK, and AKT signaling pathways and induces malignant transformation of human bronchial epithelial cells. Toxicol Sci. 125: 10-19. 2012. [Medline] [CrossRef]

16. Forbes JM, Coughlan MT, and Cooper ME. Oxidative stress as a major culprit in kidney disease in diabetes. Diabetes. 57: 1446-1454. 2008. [Medline] [CrossRef]

17. Manu KA, Shanmugam MK, Ramachandran L, Li F, Siveen KS, Chinnathambi A, Zayed ME, Alharbi SA, Arfuso F, Kumar AP, Ahn KS, and Sethi G. Isorhamnetin augments the anti-tumor effect of capeciatbine through the negative regulation of NF- $\mathrm{KB}$ signaling cascade in gastric cancer. Cancer Lett. 363: 28-36. 2015. [Medline] [CrossRef]

18. Karimi MM, Sani MJ, Mahmudabadi AZ, Jafarisani A, and Khatibi SR. Effect of acute toxicity of cadmium in mice kidney cells. Iran J Toxicol. 6: 691-698. 2012.

19. Golab F, Kadkhodaee M, Zahmatkesh M, Hedayati M, Arab H, Schuster R, Zahedi K, Lentsch AB, and Soleimani $M$. Ischemic and non-ischemic acute kidney injury cause hepatic damage. Kidney Int. 75: 783-792. 2009. [Medline] [CrossRef]

20. Prozialeck WC, and Edwards JR. Mechanisms of cadmiuminduced proximal tubule injury: new insights with implications for biomonitoring and therapeutic interventions. J Pharmacol Exp Ther. 343: 2-12. 2012. [Medline] [CrossRef]

21. Chaabane W, User SD, El-Gazzah M, Jaksik R, Sajjadi E, Rzeszowska-Wolny J, and Los MJ. Autophagy, apoptosis, mitoptosis and necrosis: interdependence between those pathways and effects on cancer. Arch Immunol Ther Exp (Warsz). 61: 43-58. 2013. [Medline] [CrossRef]

22. Cagnol S, and Chambard JC. ERK and cell death: mechanisms of ERK-induced cell death--apoptosis, autophagy and senescence. FEBS J. 277: 2-21. 2010. [Medline] [CrossRef]

23. Circu ML, and Aw TY. Glutathione and modulation of cell apoptosis. Biochim Biophys Acta. 1823: 1767-1777. 2012. [Medline] [CrossRef]

24. Chuang SY, Lin CH, and Fang JY. Natural compounds and aging: between autophagy and inflammasome. BioMed Res Int. 2014: 297293. 2014. [Medline] [CrossRef] 